ПРОБЛЕМАТИКА КАПАЦИТЕТА ЛОКАЛНИХ САМОУПРАВА ЗА ИНТЕГРАЛНУ УРБАНУ РЕГЕНЕРАЦИЈУ

\title{
CAPACITY ISSUES IN LOCAL COMMUNITIES FOR INTEGRAL URBAN REGENERATION
}

\author{
Татјана Мрђеновић* \\ рад примљен: јула 2013, рад прихваћен: децембра 2013.
}

\begin{abstract}
Апстракт
Предмет истраживања у ширем смислу представља организационо- комуникациони капацитет локалних самоуправа у Србији са аспекта одрживе урбане регенерације. У том контексту испитиваће се адекватност Фалудијевог модела мултипланерских агенција и колаборативног приступа за ефикасно и ефективно планирање у ширем процесу урбане регенерације. Уже, предмет истраживања је веза између организационих структура локалних самоуправа у Србији, односно њихов потенцијал да обезбеде адекватну комуникацију да би се добиле интегралне информације за урбану регенерацију. Проблемски оквир истраживања односи се на ефикасно и ефективно креирање решења, односно политика, планова, развојних оквира и пројеката. У конкретним условима у Србији проблемски оквир представља неадекватност наслеђеног система управљања и планирања локалном заједницом, пре свега са аспеката нивоа и врсте учешћа интересних страна у процесу креирања решења.

Хипотеза коју ово истраживање проверава односи се на успостављање везе између броја и врсте комуникационих канала које организациона структура локалних самоуправа омогућава и ефикасности и ефективности процеса урбане регенерације. Другим речима, хипотеза је: број и врста комуникационих канала (варијабла А) утиче на ефикасност и ефективност планирања за одрживу урбану регенерацију (варијабла Б). Циљеви истраживања су усмерени ка идентификовању законитости међу варијаблама. Очекиван резултат истраживања је формирање модела за мерење капацитета локалних самоупрва за интегралну урбану регенерацију.
\end{abstract}

Кључне речи: одржива урбана регенерација, интегрално урбано планирање, капацитет локалних самоуправа

\begin{abstract}
The subject of the research in wider sense is organizational-communication capacity of local communities in Serbia in the frame of sustainable development. Along with this, the paper will explore potentialities of Faludi's model of multiplanning agencies as well as Healey's collaborative theory for better efficiency and effectiveness of planning in the process of urban regeneration. Specifically the paper will research relation between organizational structure of local communities in Serbia and their potentialities to provide adequate communication towards integral information for urban regeneration. Research is framed with a problem of efficiency and effectiveness in creating urban regeneration policies, strategies, designs, and technical solutions. The problem will be focused to Serbian context; characterized with inadequate, transitional, system of governance that is moving from centralistic towards decentralist model. This will be further explored through level and type of participation in the process of urban regeneration. The hypothesis of the research explores the nature of the relation between number and types of communication channels, provided by organizational structure of local communities that should enable effectiveness and efficiency of urban regeneration. In other words the hypothesis is: number and types of communication channels (variable A) influences the effectiveness and efficiency of urban planning for sustainable urban regeneration (variable B). The aims of the paper are identification of the regulations between the variables. Expected result is establishing the model for measuring the capacity of local communities for integral urban regeneration.
\end{abstract}

Key words: sustainable urban regeneration, integral urban planning, capacity of local communities 


\section{Увод}

Развој заједница у глобалном, плуралистичком, ризичном и мрежном друштву, какво је оно данас', а у односу на ограниченост ресурса са којима располажемо (нарочито необновљивих), све више је у претходном периоду придобијао атрибут одрживог. Забринутост на глобалном нивоу, пре свега за природне и необновљиве ресурсе, надаље се проширује и на остале секторе развоја, какви су социјални, економски, културни, технолошки итд. Већ широко распрострањена дефиниција одрживог развоја, по којој он представља бригу о будућим генерацијама на начин трошења ресурса оним темпом који је у складу са циклусом обнављања њих самих или њихових супститута, у протеклим годинама бива све више појашњена кроз документе на глобалном нивоу, пре свега од стране Уједињених нација.

Тако се у Агенди 21 одрживи развој представља као интеграција сва три доминантна сектора развоја: економије, друштва у смислу једнакости и окружења - природног и створеног (UN, 1992). Ауторка сматра: „Данас се концепт најчешће тумачи, и у литератури назива, као концепт $3 \mathrm{E}$ (economy, equity and environment), где се успостављање уравнотежења три групе фактора, еколошких, економских и социјалних, сматра основом за развијање одрживих политика, планова и програма" (Bajić-Brković, 1999). Д. Ривс (Reeves) објашњава да постоје различита тумачења концепта овакве интеграције и наводи да је у онима који су највише прихваћени заступљена интеграција три, односно четири, сектора развоја (институционална одрживост) (Reeves, 2005). Србија се Националном стратегијом одрживог развоја определила за Венов дијаграм одрживог развоја, подразумевајући све принципе интеграције (Влада РС, 2009).

Значај примене концепта одрживог развоја у проблемима планирања и урбане регенерације локалних заједница постаје све више актуелан у домаћем контексту који карактеришу транзициони процеси. Иако овај рад нема за тему нити за циљ да дефинише врсте транзиционих процеса који се одвијају у Србији, они свакако представљају садашњи локални контекст. „У околностима специфичног постсоцијалистичког контекста урбаног реструктуирања, којег одликује недостатак развијених институција и одговарајућих процедура, тешко је очекивати примену прописаних процедура и вертикалну и хоризонталну хармонизацију политика просторног развоја" (Маруна, 2012: 50).

У том смислу, рад ће се ослонити на транзиционе процесе у организационом смислу са планерског и управљачког аспекта, пре свега транзиције централизованог ка децентрализованом моделу планирања и управљања развојем за урбану регенерацију у циљу интеграције нашег друштва у европске и глобалне токове. Очекивани резултат се на теоријском нивоу огледа у успостављању модела за мерење организационо-комуникационог капацитета локалних самоуправа у циљу интегралног планирања за урбану регенерацију. Метод истраживања се базира на

\footnotetext{
1 По Е. Гиденсу (Giddens) и Кастелсу (Castells) (Giddens, 2003; Castells, 2000)
}

мултидисциплинарном приступу, обзиром на то да се ради о сложеном проблему који излази из оквира планерске дисциплине и залази у поље организационих наука, политике, комуникологије, информационих технологија. Извори истраживања су писани материјали, као што су књиге, интервјуи, часописи, локални, национални и међународни документи, политике, закони, планови.

Структура истраживања одражава основну проблематику рада. У другом поглављу разматраће се појмови ефикасног и ефективног планирања у контексту одрживог развоја и урбане регенерације, односно у контексту друштвеноекономских кретања данас, нарастајућих ризика и неизвесности, конфликата, развоја модерних технологија и све веће међузависности између развојних аспеката. У трећем поглављу дефинисаће се мерљивост варијабли и постављене хипотезе. Резултат овог поглавља је поставка модела за мерење капацитета локалних самоуправа за интегрално планирање у процесу урбане регенерације.

\section{ИНТЕГРАЛНО ПЛАНИРАҢЕ У ПРОЦЕСУ УРБАНЕ РЕГЕНЕРАЦИЈЕ - ПРОБЛЕМАТИКА ЕФИКСНОСТИ И ЕФЕКТИВНОСТИ}

Циљ овог поглавља је дефинисање појмова ефикасног и ефективног планирањау контексту одрживогразвоја и урбане регенерације, односно у контексту друштвено-економских кретања данас, нарастајућих ризика и неизвесности, конфликата, развоја модерних технологија и све веће међузависности између развојних аспеката. „Промењени економски, технолошки и друштвени оквири доводе до повратних реакција у градском простору који покушава да се прилагоди (не)очекиваном убрзању модерног живота и другачијем схватању улоге урбаног окружења" (Stupar i Đukić, 2009:3).

Као кључанпринцип одрживогразвоја издваја сеинтеграција. у Агенди 21 говори се о различитим врстама интеграције: (1) интеграција три сектора развоја; (2) интеграција политика, акција, програма и планова развоја на локалном, регионалном, националном и наднационалном нивоу; (3) интеграција активности, односно њихова координација на већ поменутим управљачким нивоима; (4) интеграција свих интересних група и индивидуа у процесе доношења одлука о проблемима и темама који се тичу задовољења или угрожавања њихових интереса; (5) интеграција акција и ефеката таквих акција на окружење у смислу природног и друштвеног и економског окружења, што подразумева повратну спрегу и праћење ефеката реализације планова и политика дефинисаних кроз различите сетове индикатора (нпр. индикатори Миленијумских циљева развоја); (6) интеграција података и информација који потичу из различитих сектора развоја, као и интеграција просторних и непросторних података, кроз интегрисане базе података које обезбеђују брзу, тачну, поуздану и интегралну информацију 
коришћењем савремених ИКТ алата за управљање територијом, као што је нпр. Географски информациони систем (UN, 1992). Такође, ауторка Перић сматра: „Како би се достигла оптимална просторна организација неопходна је координација свих активности" (Perić, 2013: 2).

Ако усвојимо једну од дефиниција планирања по којој оно представља процес доношења одлука (Bajić-Brković, 1992), онда се интегрално планирање може дефинисати као процес доношења одлука који је оријентисан ка одрживом развоју, те захтева различите врсте интеграција, како између различитих дисциплина, тако и између учесника у доношењу одлука и између различитих нивоа управљања. Везано за урбану регенерацију, интегрално планирање представља једну од дисциплина која доводи до бољитка у одрживој урбаној регенерацији. Заправо, урбана регенерација представља процес ре-генерисања и осмишљавања нових вредности у циљу интеграције различитих рационалности у плуралном и мрежном друштву (Аутор 1, 2013; Аутор 1, 2011) По БајићБрковић: „Одржива урбана организација и одрживи урбани дизајн креирају места особеног карактера која испуњавају стандардне захтеве функционалности, а истовремено привлаче и плене посебношћу, атмосфером или лепотом. Таква места повезују људе и простор, кретање и урбану форму, природно и створено окружење, она представљају одговор који произилази из посебности окружења или које је комплементарно окружењу" (Bajić-Brković, 2009: 49).

у том смислу, одржива регенерација не може бити рутинизирана активност, пре свега што подразумева изналажење нових начина доласка до циљева, те она у том случају захтева креативно мишљење, које уз помоћ великог броја комуникацијских канала увећава наше знање о реалности, односно ствара холистичку слику у Ландријевом (Landry) 'креативном миљеу' (Landry, 2005). Заправо, знање о реалности није у домену једне струке, симплификовано једне индивидуе, те планирање није индивидуална активност (Bajić-Brković, 1992). Стицање знања подразумева нову информацију чији су носиоци учесници у планирању и која је продукт анализе фактографије о реалности. У том смислу, да би планирање било заиста активност кроз коју стичемо знање, односно да би од рутинизираног прерасло у креативно, неопходни су партиципација различитих учесника у планирању, као и адекватан информациони систем 0 реалности, његово успостављање и надградња.

Односно, интегрално планирање за урбану регенерацију подразумева: (1) колаборативан приступ - обезбеђује: интеграцију различитих интереса у плуралистичком друштву; (2) стратешки приступ - обезбеђује: интеграцију вредности, циљева, програма и акција; (3) системски приступ управљању - обезбеђује: интеграцију циљева, програма, акција различитих сектора развоја и њихових ефеката, интеграцију података о окружењу и из окружења.

Са друге стране, интеграција сва три, односно четири, сектора развоја у одрживом планирању може умањити ефикасност и ефективност планирања. С тим у вези, највећи аргумент који иде у прилог планирању одозго на доле јесте управо ефикасност у доношењу одлука. Сама интеграција различитих интересних група у планерском процесу може изазвати бројне конфликте и значајно успорити процес. Овај сукоб интереса може довести до нарастања конфликата чак и до нивоа поларизације, сегрегације и насиља, када стране у конфликту више нису у могућности да комуницирају, самим тим ни да креирају решења.

Да би интегрално планирање било ефикасно и ефективно, у самом процесу планирања мора се управљати конфликтима у циљу обезбеђења Хабермасове (Habermas) отворене комуникације (Habermas, 1984) између интересних страна на начин: правовремене и што потпуније информисаности интересних страна о предмету расправе, као и адекватног вођења процеса комуникације ${ }^{1}$ између интересних страна. Комуникација у таквом процесу треба да буде отворена кроз обезбеђивање различитих комуникационих канала, где је сваки интерес препознат и проблеми и решења аргументовани на адекватним подацима².

Врсте комуникационих канала у оквиру предметних приступа планирању можемо дефинисати у оквиру Фалудијевог (Faludi) модела на основу начина функционисања мултипланерских агенција (Faludi, 1984), а у Хејлиној (Healey) теорији ${ }^{4}$ на основу процеса изградње консензуса (Healey, 1997). Заједнички именитељ за обе теорије јесте стратешко планирање и креативно мишљење, стога се комуникациони канали дефинишу и стављају у њихову функцију, односно разликујемо врсте комуникационих канала који су у функцији креативног мишљења, односно креативног планирања. У том контексту, ако се кроз креативно мишљење, односно планирање, интегришу различите вредности, циљеви и интереси, онда је само интегрално планирање, поред тога што је стратешко, системско и колаборативно, у основи креативно.

Функционисање мултипланерских агенција можемо упрошћено подвести под дефинисање коначног поља алтернативних акција на свеобухватан и рационалан начин у односу на средства и циљеве. То подразумева дефинисање проблема и могућности, постављање циљева, начина њиховог достизања и евалуације (Faludi, 1984). Стога, можемо рећи да је у основи функционисања планерских агенција стратешко планирање. Такође, Хејли карактерише колаборативно планирање као стратешко, са битним разликама у односу на рационалан приступ планирању. Она каже да се вредности и циљеви као и начини њиховог достизања морају изнаћи кроз процес социјалног

2 Постоје различите дефиниције комуникације. За овај рад значајне су две Комуникација је процес преношења мисли, идеја, жеља, осећања, са једног субјекта на други; Комуникација је процес сталне - непрекидне размене информација (Tomić, 2003).

3 Према Агенди 21 адекватни подаци подразумевају: ажурност, валидност извора и тачност (UN, 1992).

4 Изабране су ове две теорије јер представљају репрезенте системскопозитивистичког и инкрементално-колабортивног приступа урбаном развоју. 
учења, односно кроз интерактивни приступ у стратешком планирању. Под стратешким планирањем Хејли подразумева креирање оквира за акцију, а не дефинисање коначног поља алтернативних акција (Healey, 1997). Иако је заједнички именитељ ова два приступа стратешко планирање, постоје разлике у самом процесу креирања стратегија и у врсти комуникационих канала које ова два приступа обезбеђују (Таб. 1).
Таб. 1.

Различитости у креирању стратегија - позитивистичкосвеобухватан и колаборативан приступ, Аутор 1 по

Хејли

Tab. 1.

Differencies between creating strategies in positivisticcomprehensive and collaborative approach, Author 1 according to Healey

\begin{tabular}{|c|c|c|}
\hline & КРЕИРАЊЕ СТРТЕГИЈА & \\
\hline & РАЦИОНАЛНО - СВЕОБУХВАТАН ПРИСТУП & КОЛАБОРАТИВАН ПРИСТУП \\
\hline $\begin{array}{l}\text { Циљ креирања } \\
\text { стратегије }\end{array}$ & Коначно дефинисано поље акцију & Дефинисање оквира за акцију \\
\hline Врста знања & 0бјективно знање & Социјално знање \\
\hline Врста веза & Веб мреже & Социјалне мреже \\
\hline Улога планера & $\begin{array}{l}\text { Планер као консултант доносиоцима одлука у } \\
\text { репрезентативној демократији }\end{array}$ & $\begin{array}{l}\text { Планер као фасилитатор1 у социјалном учењу кроз } \\
\text { изградњу консензуса }\end{array}$ \\
\hline $\begin{array}{l}\text { Улога креирања } \\
\text { стратегије }\end{array}$ & $\begin{array}{l}\text { Рационална оцена између начина постизања } \\
\text { циљева и самих циљева }\end{array}$ & $\begin{array}{l}\text { Креирање стратегија је начин да се трансформишу } \\
\text { структуре и промене односи моћи }\end{array}$ \\
\hline приступ & $\begin{array}{l}\text { Проблеми, чињенице, циљеви и вредности } \\
\text { долазе из објективног знања }\end{array}$ & $\begin{array}{l}\text { Проблеми, чињенице, циљеви и вредности долазе из } \\
\text { социјалног знања }\end{array}$ \\
\hline $\begin{array}{l}\text { Врста простора и } \\
\text { места }\end{array}$ & Институционални простор & Заједнички, дељен простор (shared place) \\
\hline $\begin{array}{l}\text { Где се креирају } \\
\text { стратегије }\end{array}$ & Јавне агенције & Социјалне арене \\
\hline & Могући простор за интеграцију & \\
\hline
\end{tabular}

Преглед дат у Таб. 1. може послужити за формирање модела интеграције комуникационих канала који задовољавају оба приступа, при чему ће се основна интеграција извршити у пољу простора за креирање стратегија. По Фалудијевом моделу тај простор је дефинисан успостављањем јавних агенција, односно мултипланерских агенција које се повезују у мрежну организацију помоћу различитих облика веб мрежа (Faludi, 1984). у Хејлином приступу овај простор је окарактерисан кроз социјалне арене у којима се кроз различите облике дебата остварује отворена комуникација и укључивост (интеграција) различитих интересних група у сам процес креирања стратегија (Healey, 1997). Сумирано, у Фалудијевом моделу комуникациони канали су институционализовани и формирају се унутар и измеђујавних агенција и надаље самог окружења, док у Хејлином приступу комуникациони канали се креирају према потребама и предмет су уједно и чврсте и меке инфраструктуре. Стога, модел за интеграцију ове две врсте комуникационих канала вршиће се доминантно у оквиру мултипланерских агенција, односно увођењем социјалног простора, односно социјалног знања у њихово функционисање. (С. 1): 


\section{Планерска агенција 1}

Планерска агенција 2

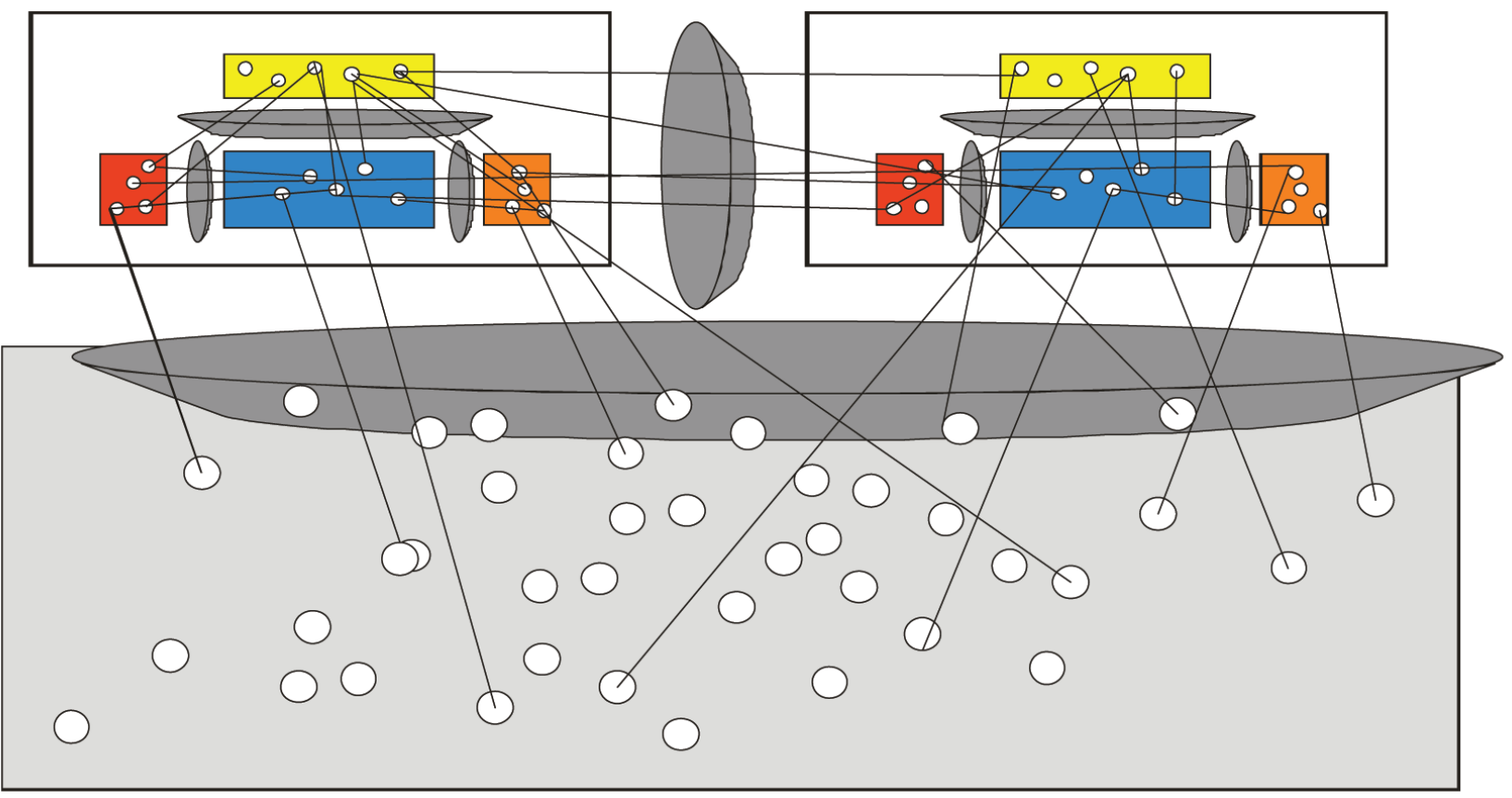

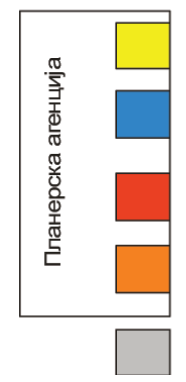

Комитет за планирање

Креирање развојног пута

Јединица за

снимање и мерење стања

Јединица за

снимање и мерење стања

Окружење
Простор за социјалну арену
Сл.1.

Модел за формализовање дивергентног мишљења кр0з просторе за изградњу консензуса око конфликтних интереса у виду социјалних арена. (Аутор 1, на основу Faludi 1984. Сл. 6.1, стр. 119)

Fig. 1.

Model for formalizing divergent thinking using social arenas as spaces for building up consensus among conflicts (Author 1 according to Faludi 1984, fig. 6.1. pp. 119)

\section{МОДЕЛ ЗА МЕРЕЊЕ КАПАЦИТЕТА ЛОКАЛНИХ САМОУПРАВА ЗА ИНТЕГРАЛНО ПЛАНИРАњЕ}

Циљ овог поглавља је да се дефинише мерљивост варијабли и постављене хипотезе. Резултат овог поглавља је поставка модела за мерење капацитета локалних самоуправа за интегрално планирање кроз сет критеријума и индикатора који су у међусобним релацијама и кроз исходе из препознатих варијабли.

У циљу извођења законитости између варијабли у постављеној хипотези биће дат приказ могућих критеријума за сваку од њих. За подсећање, варијабла А се односи на број и врсту комуникационих канала који могу варирати од случаја до случаја, у зависности од организационог модела локалне самоуправе, постојећих процедура, протокола, употребе савремених ИКТ алата, итд. Са друге стране, варијабла Б се односи на ефикасност и ефективност планирања који се огледају кроз ниво заступљености интегралног планирања у контексту одрживог развоја и урбане регенерације.

у том смислу, постављене варијабле можемо мерити на основу следећих критеријума (Шема 1): 


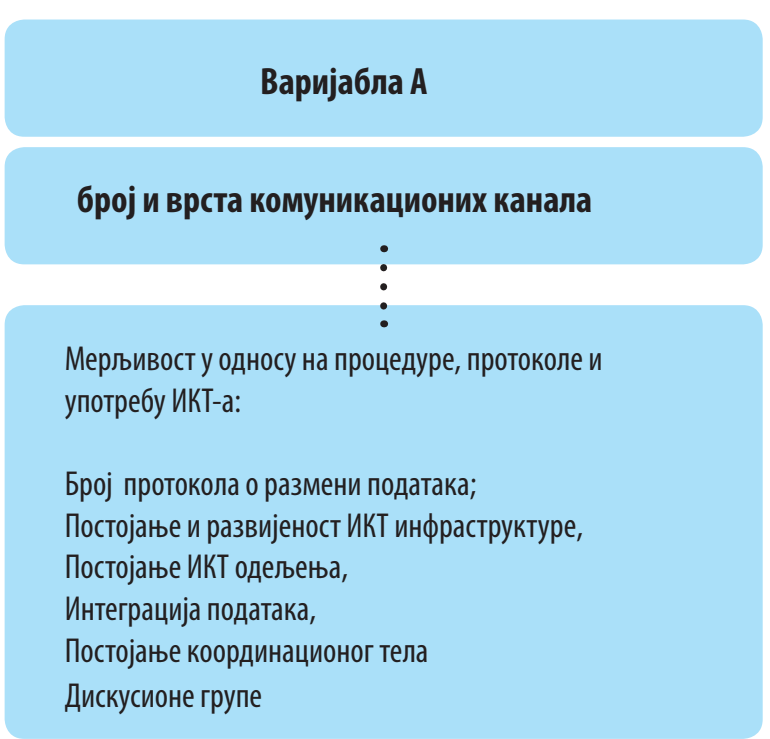

Шема 1:

Веза варијабли, критеријума и индикатора

Scheme 1:

Relation between variables, criterias and indicators

Мерљивост варијабле Б је дефинисана кроз осам критеријума који се односе на основна три принципа интегралног планирања. У том контексту критеријуми Б1, који се односе на принцип колаборације у интегралном планирању, дефинисани су кроз ниво и врсту партиципације приликом израде планских докумената. Ниво партиципације ће се разматрати у односу на активно - пасивно учешће различитих интересних група. Врста партиципације ће се разматрати у односу на укључивост различитих интересних група у односу на предмет самог планског документа. Такође, један од критеријума у оквиру ове групе ће мерити број и врсту планских докумената који су иницирани од стране невладиног сектора како би се оценила флексибилност, односно отвореност локалне самоуправе ка потребама цивилног и приватног сектора.

Следећа група критеријума у оквиру варијабле Б (Б2) односи се на стратешки приступ планских докумената и пројеката, односно на то да ли су плански документи окренути ка будућности - развоју - или решавају горуће проблеме у локалној самоуправи. Надаље, мери се број и врста планских докумената и пројеката који су проистекли из постојећих, у контексту развојности постојећих планских докумената.

Последња група критеријума Б3. односи се на системски приступ планирању, односно управљању локалном заједницом. У овој групи критеријума разматра се употреба ГИС алата у изради и имплементацији планова и пројеката, са аспекта подршке доношењу развојних одлука које се заснивају на интегралној информацији․ Такође, разматра се и врста планова у односу на то да ли су они свеобухватни или секторски и која је веза између секторских планова и свеобухватног плана развоја. Свеобухватност се односи на интеграцију четири поља одрживог развоја (економски

\section{Варијабла Б}

\section{ефикасност и ефективност планирања}

Мерљивост у односу на ниво заступљености интегралног планирања:

1. колаборативан приступ: а) ниво партиципације у изради планских докумената, б) врста партиципације у изради планских докумената, в) број и врста планова и пројеката иницираних из приватног и цивилног сектора. 2. стратешки приступ: а) методологија израде планских докумената, б) број нових пројеката и планова који су произашли из постојећих, в) врста нових пројеката и планова који су произашли из постојећих. 3. системски приступ: а) коришћење ГИС алата у доношењу развојних одлука, стратешких опредељења и у праћењу њихових ефеката на окружење, б) врста плана (секторски свеобухватни).

развој, социјални развој, унапређење животне средине, институционални развој).

Мерљивост варијабле А се поставља у односу на обезбеђење услова за ефикасно и ефективно планирање у контексту заједничког разумевања садашњег и будућег простора за акцију, односно кроз број и врсту комуникационих канала. У том смислу, комуникација се поставља као кључан фактор међусобног разумевања кроз: размену података и информација на ефикасан начин, њихову интеграцију, дискусије о кључним проблемима и развојним опредељењима итд.

На тај начин критеријуми: А1. Број протокола о размени података - обезбеђује услове за размену података између различитих одељења, јавних предузећа и институција; A2. Постојање и развијеност ИКТ инфраструктуре - обезбеђује ефикасну комуникацију у смислу брзе размене података и информација; АЗ. Постојање ИКТ одељења - обезбеђује координацију и развој информатичких активности; А4. Интеграција података - обезбеђује адекватну информацију у контексту одрживог развоја; А5. Постојање одељења за развој - обезбеђује координацију и иницијацију развојних активности; А6. и А7. Дискусионе групе - обезбеђују креативно планирање кроз интеграцију идеја, вредности, интереса, циљева и изградњу консензуса, кроз отворену комуникацију и ефикасну комуникацију. у складу са претходним формиран је модел за мерење капацитета локалних самоуправа за интегрално планирање у процесу урбане регенерације (Дијаграм 1).

7 Интегрална информација је она која учествује у креирању новог знања на интегралан начин - даје информацију о ефектима сва три сектора интегралног развоја (економија, животно окружење и друштво) (UN, 1992) 


\section{Варијабла A}

Број и врста конумикационих канала

А1. Број протокола о размени података $\rightarrow$ : д БЗ.а,ДА4.

- Ниједан

- Један

- Више

\section{A2. Постојање и развијеност ИКТ инфраструктуре $\rightarrow:$ д БЗ.а, д А4}

- Не постоји мрежа

- Постоји мрежа унутар општинске управе

- Постоји мрежа са једним JП

- Постоји мрежа са више ЈП

- Постоји мрежа са више ЈП и приватним сектором

А3. Постојање ИКТ одељења -: д Б3.а, д А2, д А4

- Не постоји

- Постоји ради на техничком одржавању хардвера и софтвера

- Постоји ради на развоју информатичких делатности

\section{А4. Интеграција података-: дБ1. б, д Б3.6}

- На нивоу општинске управе

- На нивоу општинске управе и јавних предузећа

- На нивоу општинске управе, јавних предузећа и приватног сектора

- На нивоу општинске управе, јавних предузећа и цивилног сектора

\section{А5. Постојање одељења за развој д Б1. б, дБ1. В, д Б1. г, дБ2.а д Б2.6, д Б3.б, дАЗ, д А6 \\ - Не постоји \\ - Постоји и бави се само економским развојем \\ - Постоји и бави се координацијом и усмеравањем економског, социјалног развоја, унапређења животне средине и институционалног развоја \\ - Постоји у другом или сличном облику}

A6. Постојање дискусионих група д Б1.а, д Б1. 6,

- Не постоје

- Постоје и тематски се формирају, повремено

- Постоје као сталан облик усаглашавања мишљења и интереса

\section{A7. Врста дискусионих група д Б1.а}

- Округли сто

- Радионица

- Веб дискусионе групе

\section{Варијабла Б}

Ефикасност и ефективност планирања

Б1. колаборативан приступ

а) Ниво партиципације у изради и имплементацији планских

докумената

$\rightarrow$ информисање

- консултовање

- учешће у одлучивању

Б1. колаборативан пристуг

6) Врста партиципације у изради и имплементацији планских докумената

- Интересне групе у оквиру општинске управе

- Интересне групе у оквиру општинске управе и јавних предузећа

- Интересне групе у оквиру општинске управе, јавних предузећа и приватног сектора

- Интересне групе у оквиру општинске управе, јавних предузећа, приватног и цивилног сектора

Б1. колаборативан приступ

в) Број планова и пројеката иницираних из невладиног сектора

- Ниједан

$\longrightarrow$ - Један

- Више

Б1. колаборативан приступ

г) Врста планова и пројеката иницираних из невладиног сектора

- Из сектора економског развоја

$\rightarrow$ - Из сектора социјалног развоја

- Из Сектора заштите и унапређења животне средине

- Из сектора институционалног развоја

Б2. стратешки приступ

a) Методологија израде планских докумената

- Санација постојећих проблема

- Развојно орјентисани (веза визија, стратегије, акције и имплементација)

52. стратешки приступ

6) Врста и број и нових пројеката и планова који су произашли из постојећих

- Из сектора економског развоја (број)

- Из сектора социјалног развоја (број)

- Из сектора заштите и унапређења животне средине (број)

Б3. системски пристуг

a) Коришћење ГИС алата у доношењу развојних одлука, стратешких опредељења и праћењу њихових ефеката на окружење

- Не користи се или је у зачетку

- Користи се на нивоу општинске управе и једног јавног предузећа

- К Користи се на нивоу општинске управе и више јавних предузећа

- Користи се на нивоу општинске управе и свих јавних предузећа

- Користи се на нивоу општинске управе, свих јавних предузећа и приватног сектора

- Користи се на нивоу општинске управе, свих јавних предузећа, приватног и цивилног

Б3. системски пристуг

6) Врста плана, њихов број и веза са осталим плановима (секторски (веобухватни)

- Из сектора економског развоја (број и веза: не постоји веза, индиректно у $ф$-ји, директно у $\phi$-ји)

- Из сектора социјалног развоја (број и веза: не постоји веза,

индиректно у $\phi$-ји, директно у $\phi$-ји)

- Из сектора заштите и унапређења животне средине (број и веза: не постоји веза, индиректно у $\phi$-ји, директно у $\phi$-ји)

- Свеобухватни план - интегралан развој сва три односно четири

\section{Дијаграм 1:}

Модел за мерење капацитета локалних самоуправа за интегрално планирање у процесу урбане регенерације Diagram 1:

Model for measuring capacities of local communities for integral urban planning in the process of urban regeneration
Поставка модела за мерење подразумева дефинисане индикаторе у односу на критеријуме (елементе) постављених варијабли. Такође, препознате су везе између елемената варијабли које имају директан утицај.

(коришћење различитих боја у успостављању релација је искључиво због боље прегледности) 


\section{ЗАКЉУЧНА РАЗМАТРАњА}

Ефикасност и ефективност планирањау контексту савремених друштвених, политичких и економских кретања које одликују глобализација, мрежно и плуралистичко друштво, посматра се у оквиру одрживог развоја. Као један од основних принципа одрживог развоја издваја се интеграција четири развојна сектора: економија, друштво, животна средина и институционални развој.У том смислу, ефикасно и ефективно планирање представља пресечни скуп ова четири развојна поља, односно побољшање - у једном развојном сектору требало би да утичу на побољшања или барем да спрече нарушавање преостала три развојна сектора.

С тим у вези, ефикасно и ефективно планирање може се окарактерисати као интегрално планирање, односно планирање усмерено ка одрживом развоју. Интегрално планирање подразумева: (1) колаборативан приступ - обезбеђује: интеграцију различитих интереса у плуралистичком друштву, (2) стратешки приступ обезбеђује: интеграцију вредности, циљева, програма и акција, (3) системски приступ управљању - обезбеђује: интеграцију циљева, програма, акција различитих сектора развоја и њихових ефеката, интеграцију података о окружењу и из окружења.

Фалудијев и Хејлин приступ планирању говоре 0 две врсте интеграције у процесу планирања. Фалуди ставља акценат на интеграцију елемената процеса планирања и координацију активности у самом процесу планирања и имплементацији решења. Иако делује да је његов модел заснован на дедуктивном приступу, Фалуди говори о великом значају постојања хоризонталних веза које омогућавају размену мишљења, идеја, виђења, што води ка интеграцији различитих вредности и интереса, иако он не говори о самом процесу такве интеграције. За разлику од Фалудија, Хејли акценат ставља на изградњу консензуса, односно на процес интеграције различитих интереса у плуралистичком друштву, који доводи до ефикасног и ефективног креирања решења (политика, стретегија, програма акција, итд.).

Фалудијеве планерске и мултипланерске агенције могу представљати модел за интегрално планирање у контексту одрживог развоја, с тим да се њихов комуникативни простор веб мрежа оплемени простором социјалних арена, што би адаптирало овај модел у контексту плуралистичког друштва, односно учесници у грађењу консензуса не би биле само планерске агенције, већ и све интересне стране у коегзистирајућем простору. Креирање стратешких циљева, програма и акција би се одвијало паралелно у два простора, социјалном и институционалном.

Очекивани резултати истраживања били су усмерени ка препознавању законитости веза између броја и врсте комуникационих канала и ефикасности и ефективности планирања у процесу урбане регенерације. У том смислу, креиран модел за мерење организационо-комуникационог капацитета локалних самоуправа може послужити и за наредна истраживања овог типа, с тим да треба обратити пажњу на, сада већ чињеницу, да постоје двосмерне везе између елемената постављених варијабли, и то у случају врсте и нивоа партиципације у изради планских докумената, што представља један од елемената ефикасног и ефективног планирања, као и на интеграцију података, јер је у одрживом развоју свако корисник и носилац података и информација. С тим у вези, у наредним истраживањима овог типа, требало би употпунити постављени модел и преиспитати утицај интегралног планирања на број и врсту комуникационих канала.

\section{Захвалнице}

Истраживање представља резултат рада на научноистраживачком пројекту: ТР36035 Просторни, еколошки, енергетски и друштвени аспекти развоја насеља и климатске промене - међусобни утицаји, финансираном од стране Министарства просвете, науке и технолошког развоја.

\section{Литература:}

Bajić-Brković, M. (1999) Održivost i grad, Beograd, Arhitektonski fakultet Univerziteta u Beogradu

Bajić-Brković, M. (1992) Predavanja iz urbanističkog i prostornog planiranja, Beograd, Arhitektonski fakultet Univerziteta u Beogradu

Castells, M. (2000) The Rise of the Network Society, Oxford, Blackwell Publishing

Faludi, A. (1984) Planning Theory, Oxford, Pergamon press

Giddens, A. (2003): Sociologija, Beograd, Ekonomski fakultet u Beogradu

Habermas, J. (1984) The Theory of Communicative Action - Volume One: Reason and the Rationalization of Society, Boston, Beacon Press

Healey, P. (1997) Collaborative Plannig: Shaping Places in Fragmenteted Societies, London, MACMILLAN PRESS LTD.

Landry, C. (2005)The Creative City: A Toolkit for Urban Innovators, London, Earthscan

Mrđenović, T. (2011): Integrative Urban Design in Regeneration Principles for Achieving Sustainable Places. Journal of Applied Engineering Science No. 9(2011)2, 305-316.

Mrđenović, T. (2013): Urban regeneration: Questioning the subject. TTEM-Technics Technologies Education Management, Vol 8, No3

Perić, A. (2013) The Review of Planning Practice in Brownfield Regeneration - Some European Experiances, Journal of Applied Engineering Science, $1-8$.

Reeves, D. (2005) Planning for Diversity: Policy and Planning in a World of Difference, New York, Routledge

Stupar, A., \& A. Đukić (2009): Urbani menadžment - od teorije do prakse, od vizije do realizacije, Arhitektura i urbanizam, 3-7.

Tomić, Z. (2003) Komunikologija, Beograd, Čigoja

UN (1992, June 14), Agenda 21, Retrieved 2004, from www. un.org/esa/dsd/agenda21.

http://www.un.org/millenniumgoals/environ.shtml.

Bajić-Brković, M. (2009) Mogu li kreativne ekonomije da proizvode održiva rešenja? Neka evropska iskustva, Arhitektura i urbanizam, $47-60$.

Valada RS (2009): Nacionalna strategija održivog razvoja. Održivi razvoj Srbije: Naša zajednička budućnost, Beograd, Republika Srbija, Ministarstvo za nauku i tehnološki razvoj i Kabinet potpredsednika Vlade za evropske integracije.

Maruna, M. (2012) Regionalne strategije prilagođavanja klimatskim promenama: Smernice za urbanističko planiranje u Srbiji, Arhitektura i urbanizam, 50 - 56. 